Bul. Agrohorti 3 (2) : 263 - 275 (2015)

\title{
Pengaruh Jenis Pupuk Organik terhadap Pertumbuhan dan Hasil, Panen Tanaman Sayuran di dalam Nethouse
}

\author{
Effect of Organic Fertilizer's Source on the Growth and Yield of Vegetable Crop in a Nethouse \\ Anita Maryam, Anas D. Susila*, dan Juang Gema Kartika
}

Agronomi dan Hortikultura, Fakultas Pertanian, Institut Pertanian Bogor

(Bogor Agricultural University), Jl. Meranti, Kampus IPB Darmaga, Bogor 16680, Indonesia

Telp.\&Faks.62-251-8629353 e-mail agronipb@indo.net.id

*Penulis untuk korespondensi: anasdsusila@ymail.com

Disetujui 7 Mei 2015 / Published online 15 Mei 2015

\begin{abstract}
Fertilizer is one of mayor factor that influence vegetable growth and yield. The objectives of this research was to study the effect of several organic fertilizers source on growth and yield of caisin, kangkong, pakchoy and lettuce. The research was series of experiment with four vegetable crop: caisin, kangkong, pakchoy and lettuce. Treatments were arranged in randomize complete block design with three replications and consist of three organic fertilizers source (chiken manure, cow manure, compost with 20 tha rate and control/no organic fertilizer amendment). The growth and yield of vegetable significantly influenced by the source of organic fertilizer. Chiken manure application obtained maximum plant height and number of leaves of caisin, kangkong, pakchoy and lettuce. Chiken manure also obtained the highest shoot weight and root weight of caisin, kangkong and pakchoy. On the other, cow manure gave the greatest root length of lettuce.
\end{abstract}

Keywords : chicken manure, cow manure, compost, growth, yield, vegetable

\section{ABSTRACT}

Pupuk merupakan salah satu faktor yang dapat mempengaruhi pertumbuhan dan produksi tanaman sayur. Penelitian ini bertujuan mempelajari pengaruh beberapa sumber pupuk organik terhadap pertumbuhan dan produksi hasil caisin, kangkung, pakcoi, dan selada. Penelitian ini dilakukan secara seri dengan empat tanaman sayur : caisin, kangkung, pakcoi, dan selada. Perlakuan menggunakan Rancangan Kelompok Lengkap Teracak sebanyak tiga ulangan yang terdiri dari sumber pupuk organik (pupuk kandang ayam, pupuk kandang sapi, kompos 20 ton $\mathrm{ha}^{-1}$ dan kontrol/tanpa penggunaan pupuk organik). Pertumbuhan dan hasil produksi tanaman sayur berpengaruh sangat nyata oleh pemberian pupuk organik, Perlakuan pemberian pupuk kandang ayam menghasilkan tinggi tanaman dan jumlah daun lebih banyak pada tanaman caisin, kangkung, dan selada. Pemberian pupuk kandang ayam juga menghasilkan berat batang dan berat akar tertinggi pada tanaman caisin, kangkung, dan pakcoi. Selain itu, pemberian pupuk kandang sapi memberikan panjang akar terbesar pada selada.

Kata kunci : pupuk kandang ayam, pupuk kandang sapi, kompos, pertumbuhan, sayuran 


\section{PENDAHULUAN}

Jumlah penduduk Indonesia yang meningkat dari 179 juta jiwa pada tahun 1990 menjadi 206 juta jiwa tahun 2000 (Badan Pusat Statistik, 2005) menyebabkan meningkatnya kebutuhan pangan, termasuk sayuran. Produksi selada Indonesia tahun 2005 yaitu dibawah 1000 ton sedangkan nilai konsumsi selada sebesar 300 ribu ton (Food Agriculture Organisation, 2007a). Produksi crucifera tahun 2005 sebesar 1.29 juta ton dan konsumsi komoditas ini adalah 1.26 juta ton (Food Agriculture Organisation, 2007). Produksi kangkung Indonesia tahun 2005 adalah 229.99 ton sedangkan konsumsi mencapai 1.02 juta ton (Direktorat Jenderal Hortikultura, 2008). Dikaitkan dengan ketahanan pangan maka dibutuhkan upaya peningkatan pangan dengan laju yang tinggi dan berkelanjutan sehingga dapat meningkatkan volume pemasaran sayuran untuk memenuhi kebutuhan yang belum tercukupi.

Faktor penting yang mempengaruhi peningkatan produktivitas sayuran adalah pemupukan namun penggunaan pupuk anorganik sintetis secara terus menerus mengakibatkan pengurasan hara $\mathrm{S}, \mathrm{Ca}, \mathrm{Mg}, \mathrm{Zn}$ dan $\mathrm{Cu}$ (Las et al., 2006). Dengan demikian, diperlukan penggunaan pupuk organik sebagai bahan amelioran tanah. Bahan organik yang terkandung dalam pupuk organik dapat meningkatkan pertumbuhan dan hasil panen tanaman. Krishnawati (2003) melaporkan bahwa tanaman kentang dengan perlakuan kascing $1 \mathrm{~kg} /$ tanaman menghasilkan tinggi dan bobot basah tajuk berturut-turut 35 dan $14 \%$ lebih besar dibandingkan perlakuan tanpa kascing.

Selain pemupukan, budidaya sayuran yang berkelanjutan disertai dengan penggunaan sistem pengendalian Organisme Pengganggu Tanaman (OPT). Salah satu sistem pengendalian OPT adalah penggunaan nethouse. Nethouse dapat mengurangi serangan OPT tanpa menggunakan pestisida sintetik. Singh et al. (2006) melaporkan bahwa tingkat gejala Leaf Curl Virus (LCV) akibat serangan vektor Bemisia tabaci pada daun cabai berbeda antara yang ditanam dalam nethouse dengan tanpa nethouse. Mesh 50 x 50 lubang per $\mathrm{cm}^{2}$ memiliki gejala LCV terendah (16.8\%), mesh 40 x 40 lubang per $\mathrm{cm}^{2}$ memiliki tingkat gejala $22.7 \%$ dan tanaman yang ditanam tanpa nethouse memiliki gejala LCV tertinggi (95.1\%). Hasil penelitian tersebut menunjukkan bahwa kualitas tanaman dapat dipertahankan tanpa menimbulkan dampak pencemaran bagi lingkungan akibat penggunaan pestisida. Penelitian ini bertujuan untuk menguji pengaruh beberapa jenis pupuk organik terhadap pertumbuhan dan hasil panen caisin, kangkung, pakcoi dan selada pada budidaya di dalam nethouse

\section{BAHAN DAN METODE}

Penelitian dilaksanakan di dalam nethouse Unit Lapangan Darmaga, University Farm, IPB Darmaga, Bogor. Lokasi ini memiliki jenis tanah liat, ketinggian $250 \mathrm{~m}$ dpl. Penelitian dilaksanakan mulai Februari hingga Mei 2008. Varietas tanaman yang digunakan adalah caisin 'Tosakan', kangkung 'Niagara', pakcoi 'Gardena' dan selada keriting 'Chia Tai'. Bahan lain yang digunakan adalah kascing dengan komposisi campuran dari pupuk kandang sapi dan kotoran cacing, pupuk kandang ayam, pupuk kandang sapi serta pupuk kompos.

Alat yang digunakan yaitu tray semai (128 lubang/tray), timbangan analitik, termometer (HaarSynth. Hygro. Germany), sistem irigasi dan nethouse. Sistem irigasi yang digunakan adalah irigasi permukaan. Nethouse yang digunakan berasal dari bahan mesh putih berukuran $6 \times 16 \mathrm{~m}$.

Percobaan ini merupakan percobaan seri yang masing-masing dilakukan terhadap caisin, kangkung, pakcoi dan selada. Rancangan percobaan yang digunakan adalah Rancangan Kelompok Lengkap Teracak (RKLT). Pupuk organik yang digunakan sebagai perlakuan yaitu pupuk kandang ayam (M1), pupuk kandang sapi (M2), pupuk kompos (M3) dan tanpa pupuk organik atau kontrol (M4). Setiap perlakuan diulang 3 kali sehingga terdapat 12 satuan percobaan. Untuk mengetahui pengaruh perlakuan, data yang diperoleh dianalisis dengan sidik ragam (uji F). Jika hasil sidik ragam menunjukkan perbedaan yang nyata maka dilakukan uji lanjut dengan tukey pada taraf $5 \%$.

Benih sayuran terlebih dahulu disemai dalam tray semai dengan media kascing. Transplanting dilakukan pada 4 minggu setelah semai. Jarak tanam yang digunakan $0.25 \mathrm{~m}$ x 0.20 $\mathrm{m}$. Pengolahan lahan dilakukan sebelum tanam dengan membuat bedeng berukuran $1 \times 2.2 \mathrm{~m}$. Dua minggu sebelum tanam, pupuk disebarkan ke lahan dengan dosis 20 ton/ha atau $7.8 \mathrm{~kg} /$ bedeng. Pemeliharaan awal dilakukan dengan menyulam tanaman yang mati. Selain penyulaman, dilakukan penyiangan gulma, penyiraman dan pengendalian hama penyakit. Pemanenan dilakukan dengan cara mencabut tanaman beserta akarnya. Panen 
dilakukan ketika tanaman telah mencapai kondisi siap panen.

\section{Pengamatan}

Pengamatan yang dilakukan adalah pengukuran suhu dan kelembaban udara $(\mathrm{RH})$ di dalam nethouse, yang dilakukan setiap hari. Pengamatan pertumbuhan caisin, pakcoi dan selada dilakukan satu minggu sekali sedangkan pengamatan kangkung dilakukan setiap lima hari. Pengamatan terdiri atas :

Tinggi Tajuk $(\mathrm{cm})$. Tinggi tajuk pada caisin, pakcoi dan selada diukur dari kotiledon hingga ujung daun terpanjang sedangkan pada kangkung diukur dari kotiledon hingga titik tumbuh.

Panjang Daun dan Lebar Daun (cm). Panjang daun diukur pada daun yang terpanjang sedangkan lebar daun diukur pada daun yang terpanjang di bagian tengahnya.

Jumlah Daun (helai). Jumlah daun diamati dengan menghitung daun yang telah membuka penuh.

Pengamatan lainnya yang dilakukan setelah panen yaitu; bobot basah tajuk per tanaman $(\mathrm{g})$, bobot basah tajuk per bedeng $(\mathrm{g})$, bobot layak pasar per bedeng $(\mathrm{g})$, panjang akar $(\mathrm{cm})$, bobot basah akar per tanaman (g) dan bobot basah akar per bedeng $(\mathrm{g})$. Bobot layak pasar per bedeng yaitu bobot hasil panen per bedeng dikurangi dengan bagian yang rusak.

\section{HASIL DAN PEMBAHASAN}

Pupuk kandang ayam memiliki kandungan hara tertinggi dibandingkan jenis pupuk organik lainnya. Berdasarkan hasil analisis, pupuk kandang ayam mengandung $1.40 \% \quad \mathrm{~N}, 1.34 \% \mathrm{P}_{2} \mathrm{O}_{5}$ dan $2.30 \% \mathrm{~K}{ }_{2} \mathrm{O}$, pupuk kandang sapi mengandung $0.46 \% \mathrm{~N}, 0.83 \% \quad \mathrm{P}_{2} \mathrm{O}_{5}, 0.30 \% \quad \mathrm{~K}_{2} \mathrm{O}$ dan pupuk kompos mengandung $0.51 \% \quad \mathrm{~N}, \quad 0.26 \% \quad \mathrm{P}_{2} \mathrm{O}_{5}$, $0.08 \% \mathrm{~K}_{2} \mathrm{O}$. Hasil analisis tanah menunjukkan bahwa C-Organik tergolong sedang yaitu $2.04 \%$, $\mathrm{N}$-Total rendah $(0.18 \%)$, P-tersedia sangat rendah $(2.90 \mathrm{ppm}), \quad$ K-tersedia sangat rendah $(0.03$ $\mathrm{me} / 100 \mathrm{~g})$.

\section{Caisin (Brassica juncea)}

Tabel 1 menunjukkan perlakuan jenis pupuk organik memberikan pengaruh sangat nyata terhadap tinggi tanaman pada 1 dan 2 MST, panjang daun pada 1 dan 4 MST, lebar daun pada 1, 3 dan 4 MST dan pada seluruh komponen hasil panen.

Tabel 1. Rekapitulasi sidik ragam hasil percobaan pada caisin Tosakan

\begin{tabular}{lcccc}
\hline \multicolumn{1}{c}{ Peubah } & Umur Tanaman (MST) & & \\
\cline { 2 - 5 } \multicolumn{1}{c}{} & 1 & 2 & 3 & 4 \\
\hline Tinggi Tanaman & $* *$ & $* *$ & $*$ & $*$ \\
Panjang Daun & $* *$ & $*$ & $*$ & $* *$ \\
Lebar Daun & $* *$ & $*$ & $* *$ & $* *$ \\
Jumlah Daun & $*$ & $*$ & tn & tn \\
Bobot Tajuk/Tanaman & - & - & - & $* *$ \\
Bobot Tajuk/Bedeng & - & - & - & $* *$ \\
Bobot Layak Pasar/Bedeng & - & - & - & $* *$ \\
Panjang Akar & - & - & - & $* *$ \\
Bobot Akar/Tanaman & - & - & - & $* *$ \\
Bobot Akar/Bedeng & - & - & - & $* *$ \\
\hline
\end{tabular}

Keterangan : tn = tidak berbeda nyata; *= berbeda nyata pada uji F 5\%; **= berbeda sangat nyata pada uji F 1\%; - = tidak dilakukan pengamatan; MST = minggu setelah tanam

Pupuk kandang ayam menghasilkan tinggi tanaman terbesar. Tabel 2 menunjukkan bahwa perlakuan pupuk kandang ayam meningkatkan tinggi tanaman sebesar $358.93 \%$ dibandingkan kontrol pada 4 MST. 
Bul. Agrohorti 3 (2) : $262-275$ (2015)

Tabel 2. Rata-rata tinggi tanaman caisin Tosakan pada berbagai jenis pupuk organik

\begin{tabular}{|c|c|c|c|c|}
\hline \multirow{2}{*}{ Jenis Pupuk Organik } & \multicolumn{3}{|c|}{ Umur (MST) } & \multirow[b]{2}{*}{4} \\
\hline & 1 & 2 & 3 & \\
\hline & & & cm --- & \\
\hline Pukan Ayam & $11.29 \mathrm{a}$ & $16.65 \mathrm{a}$ & $22.53 \mathrm{a}$ & $30.84 a$ \\
\hline Pukan Sapi & $8.31 \mathrm{~b}$ & $11.45 \mathrm{ab}$ & $14.14 \mathrm{ab}$ & $23.09 \mathrm{~b}$ \\
\hline Kompos & $7.03 b$ & $8.47 \mathrm{~b}$ & $8.85 \mathrm{~b}$ & $11.1 \mathrm{c}$ \\
\hline Kontrol & $5.97 \mathrm{~b}$ & $6.26 \mathrm{~b}$ & $6.65 \mathrm{~b}$ & $6.72 \mathrm{c}$ \\
\hline
\end{tabular}

Keterangan: Angka yang diikuti oleh huruf yang berbeda pada kolom yang sama menunjukkan berbeda nyata berdasarkan uji tukey pada taraf 5\%.

Pemberian pupuk kandang ayam maupun kontrol. Panjang daun meningkat 213.93\% menghasilkan panjang daun lebih tinggi dibandingkan kontrol pada 4 MST (Tabel 3).

dibandingkan pupuk kandang sapi, pupuk kompos

Tabel 3. Rata-rata panjang daun caisin Tosakan pada berbagai jenis pupuk organik

\begin{tabular}{|c|c|c|c|c|}
\hline \multirow{2}{*}{ Jenis Pupuk Organik } & \multicolumn{3}{|c|}{ Umur (MST) } & \multirow[b]{2}{*}{4} \\
\hline & 1 & 2 & 3 & \\
\hline & \multicolumn{4}{|c|}{---- cm ---- } \\
\hline Pukan Ayam & $6.63 \mathrm{a}$ & $8.72 \mathrm{a}$ & $11.95 \mathrm{a}$ & $13.97 \mathrm{a}$ \\
\hline Pukan Sapi & $3.93 b$ & $6.45 \mathrm{ab}$ & $7.91 \mathrm{~b}$ & $12.67 \mathrm{a}$ \\
\hline Kompos & $3.09 \mathrm{~b}$ & $4.86 \mathrm{~b}$ & $5.28 b$ & $6.34 b$ \\
\hline Kontrol & $3.04 \mathrm{~b}$ & $3.73 b$ & $5.80 \mathrm{~b}$ & $4.45 \mathrm{~b}$ \\
\hline \multicolumn{5}{|c|}{$\begin{array}{l}\text { Keterangan: Angka yang diikuti oleh huruf yang berbeda pada kolom yang sama menunjukkan berbeda nyata berdasarkan uji tukey pada } \\
\text { taraf } 5 \%\end{array}$} \\
\hline $\begin{array}{l}\text { Jenis pupuk organik terlihat } \\
\text { pengaruhnya terhadap peubah lebar daun. } \\
\text { kandang ayam menghasilkan lebar daun } \\
\text { tertinggi diantara jenis pupuk organik }\end{array}$ & $\begin{array}{l}\text { yata } \\
\text { puk } \\
\text { isin } \\
\text { ang }\end{array}$ & $\begin{array}{l}\text { digunakan. } \\
\text { dengan perl } \\
\text { peningkatan } \\
\text { pada } 4 \text { MST }\end{array}$ & $\begin{array}{l}4 \text { menu } \\
\text { puk kand } \\
286.36 \%\end{array}$ & $\begin{array}{l}\text { lebar daun } \\
\text { mengalami } \\
\text { kan kontrol }\end{array}$ \\
\hline
\end{tabular}

Tabel 4. Rata-rata lebar daun caisin Tosakan pada berbagai dosis pupuk

\begin{tabular}{|c|c|c|c|c|}
\hline \multirow{2}{*}{ Jenis Pupuk Organik } & \multicolumn{4}{|c|}{ Umur (MST) } \\
\hline & 1 & 2 & 3 & 4 \\
\hline & \multicolumn{4}{|c|}{--------- cm --------- } \\
\hline Pukan Ayam & $3.70 \mathrm{a}$ & $5.04 \mathrm{a}$ & $7.51 \mathrm{a}$ & $7.65 \mathrm{a}$ \\
\hline Pukan Sapi & $2.93 \mathrm{ab}$ & $4.03 \mathrm{ab}$ & $4.91 \mathrm{ab}$ & $6.48 \mathrm{a}$ \\
\hline Kompos & $2.07 \mathrm{bc}$ & $2.27 \mathrm{~b}$ & $2.96 \mathrm{~b}$ & $3.34 \mathrm{~b}$ \\
\hline Kontrol & $1.86 \mathrm{c}$ & $1.88 \mathrm{~b}$ & $1.94 \mathrm{~b}$ & $1.98 \mathrm{~b}$ \\
\hline
\end{tabular}

Keterangan : Angka yang diikuti oleh huruf yang berbeda pada kolom yang sama menunjukkan berbeda nyata berdasarkan uji tukey pada taraf $5 \%$.

Jumlah daun dengan pemberian pupuk kandang ayam lebih tinggi dibandingkan dengan pupuk kandang sapi, pupuk kompos maupun kontrol. Tabel 5 menunjukkan bahwa pupuk kandang ayam meningkatkan jumlah daun sebesar $65.53 \%$ dibandingkan kontrol pada 2 MST 
Bul. Agrohorti 3 (2) : 263 - 275 (2015)

Tabel 5. Rata-rata jumlah daun caisin Tosakan pada berbagai jenis pupuk organik

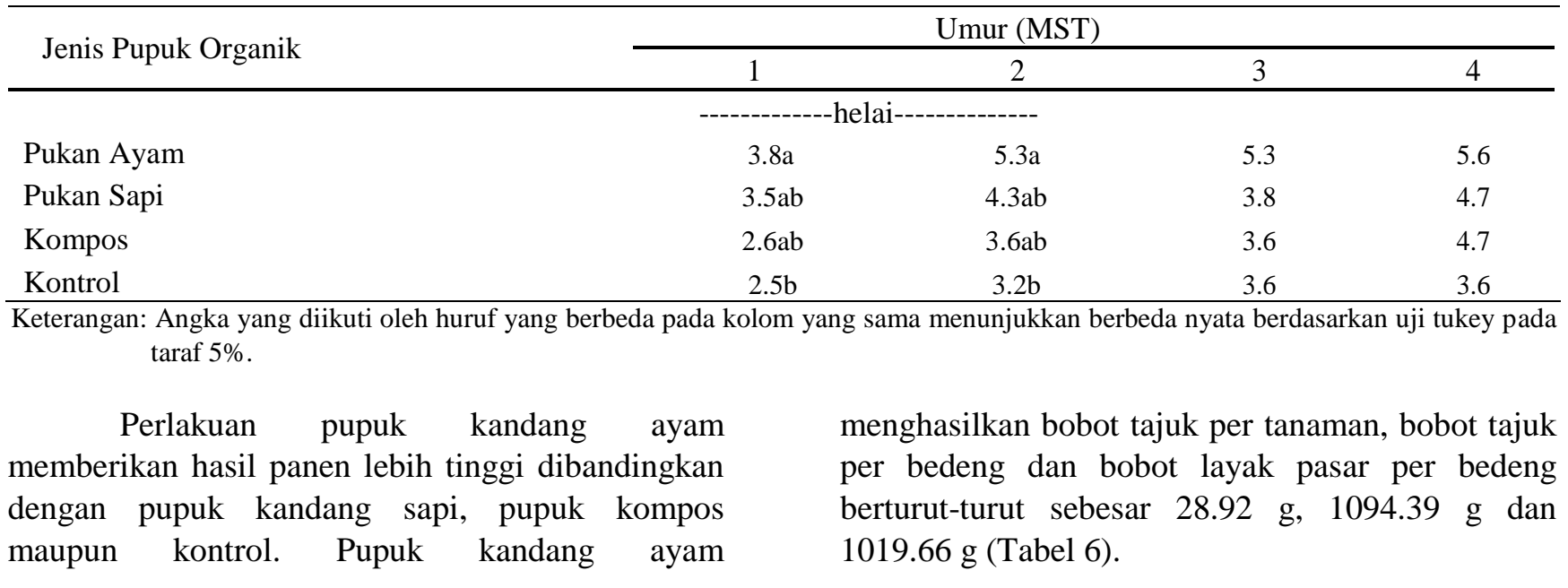

Tabel 6. Rata-rata hasil panen tajuk caisin Tosakan pada perlakuan jenis pupuk organik

\begin{tabular}{lccc}
\hline $\begin{array}{c}\text { Jenis Pupuk } \\
\text { Organik }\end{array}$ & $\begin{array}{c}\text { Bobot Tajuk } \\
\text { per Tanaman }\end{array}$ & $\begin{array}{c}\text { Bobot } \\
\text { Tajuk per } \\
\text { Bedeng }\end{array}$ & $\begin{array}{c}\text { Bobot Layak } \\
\text { Pasar per } \\
\text { Bedeng }\end{array}$ \\
\hline Pukan Ayam & $28.92 \mathrm{a}$ & $1094.39 \mathrm{a}$ & $1019.66 \mathrm{a}$ \\
Pukan Sapi & $7.01 \mathrm{~b}$ & $249.63 \mathrm{~b}$ & $236.77 \mathrm{~b}$ \\
Kompos & $3.25 \mathrm{bc}$ & $103.48 \mathrm{~b}$ & $98.63 \mathrm{bc}$ \\
Kontrol & $1.34 \mathrm{c}$ & $21.52 \mathrm{~b}$ & $0.00 \mathrm{c}$ \\
\hline $\begin{array}{l}\text { Keterangan: Angka yang diikuti oleh huruf yang berbeda pada kolom yang sama } \\
\text { taraf 5\% }\end{array}$ &
\end{tabular}

Tanaman dengan pemberian pupuk kandang ayam memiliki panjang akar tertinggi diantara jenis pupuk organik lain. Panjang akar, bobot akar per tanaman dan bobot akar per bedeng meningkat $199.00 \%, \quad 209.52 \%$ dan $914.36 \%$ dibandingkan kontrol (Tabel 7).

Tabel 7. Rata-rata hasil panen akar caisin Torakan pada perlakuan jenis pupuk organik

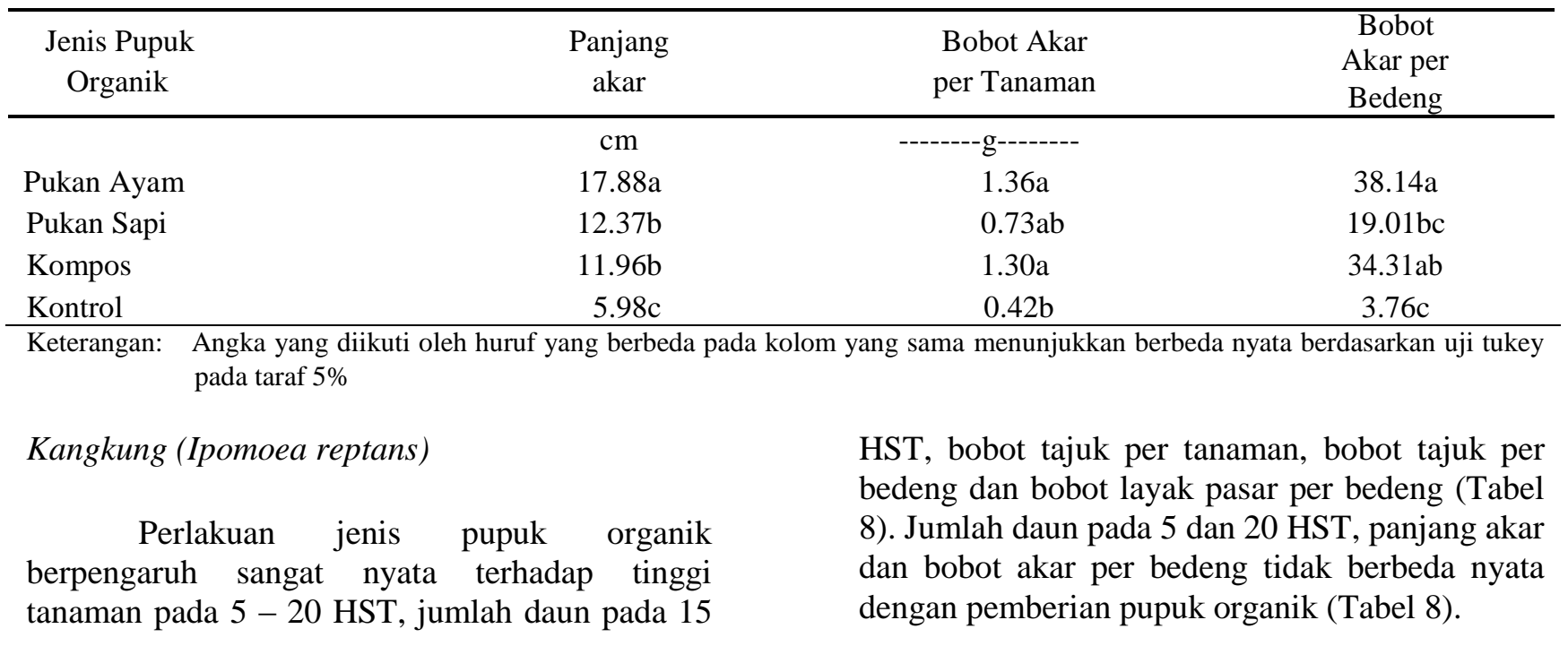


Tabel 8. Rekapitulasi sidik ragam hasil percobaan pada kangkung Niagara

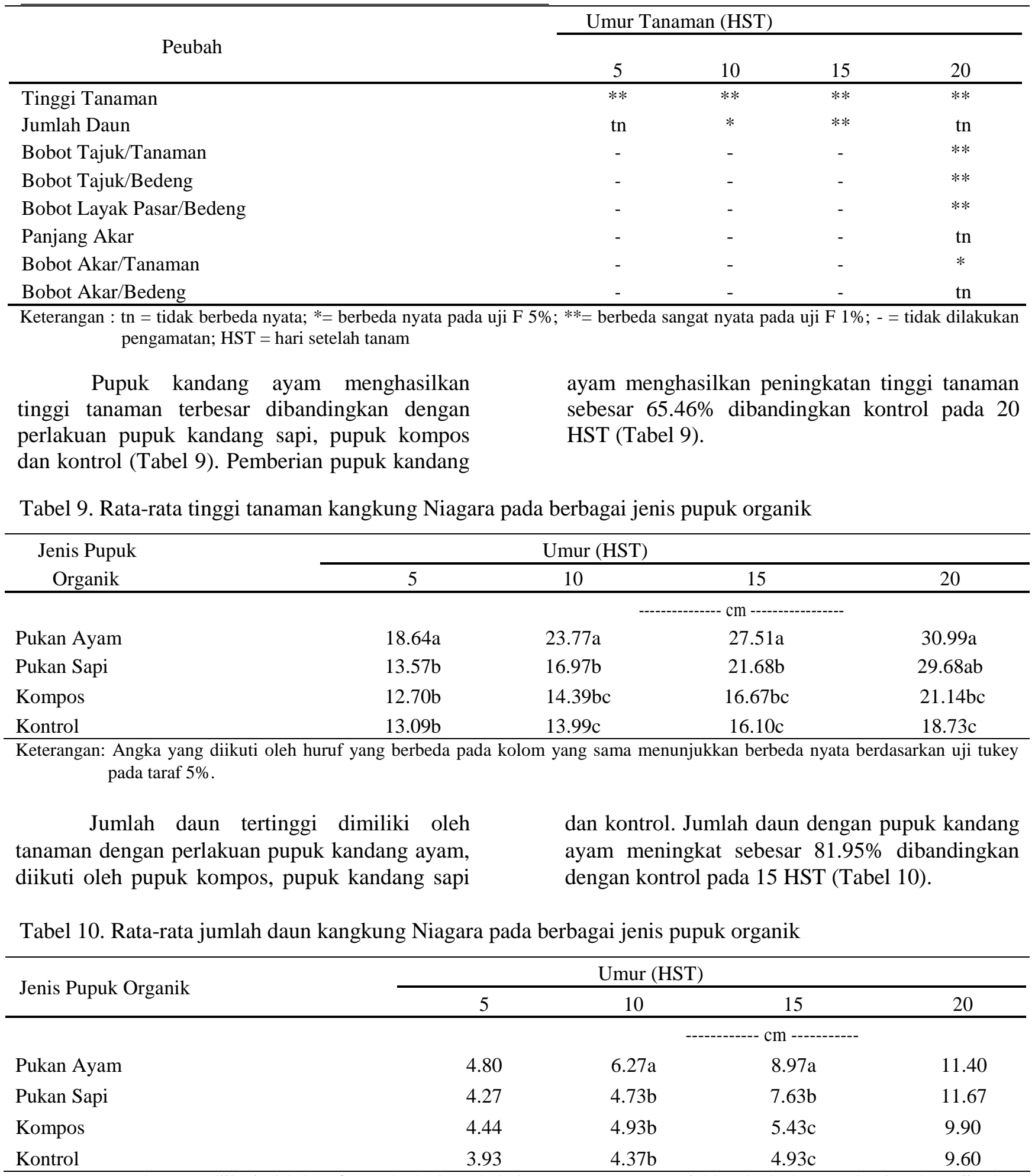

Keterangan: Angka yang diikuti oleh huruf yang berbeda pada kolom yang sama menunjukkan berbeda nyata berdasarkan uji tukey pada taraf $5 \%$.

Perlakuan pupuk kandang ayam memberikan hasil panen tajuk tertinggi dibandingkan dengan jenis pupuk organik lainnya.
Tabel 11 menunjukkan pemberian pupuk kandang ayam meningkatkan bobot tajuk per tanaman dan bobot tajuk per bedeng sebesar $61.90 \%$ dan $146.69 \%$ dibandingkan kontrol. 
Bul. Agrohorti 3 (2) : 263 - 275 (2015)

Tabel 11. Rata-rata hasil panen tajuk kangkung Niagara pada berbagai jenis pupuk organik

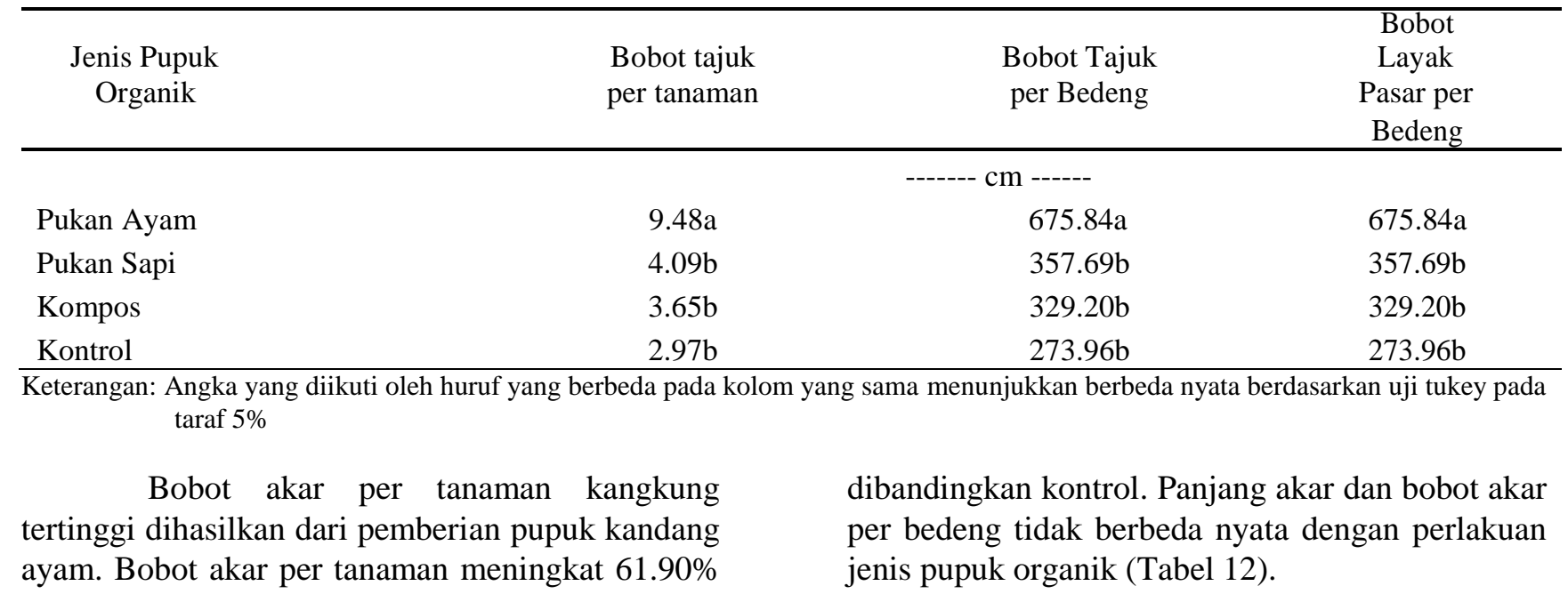

Tabel 12. Rata-rata hasil panen akar kangkung 'Niagara' pada perlakuan jenis pupuk organik

\begin{tabular}{|c|c|c|c|c|c|}
\hline $\begin{array}{c}\text { Jenis Pupuk } \\
\text { Organik }\end{array}$ & $\begin{array}{c}\text { Panjang } \\
\text { akar }\end{array}$ & & & \multicolumn{2}{|c|}{$\begin{array}{l}\text { Bobot Akar } \\
\text { per Bedeng }\end{array}$} \\
\hline & $\mathrm{cm}$ & \multicolumn{2}{|c|}{---------g--------. } & \\
\hline Pukan Ayam & 13.63 & \multicolumn{2}{|c|}{$1.02 \mathrm{a}$} & \multicolumn{2}{|c|}{87.24} \\
\hline Pukan Sapi & 15.27 & \multicolumn{2}{|c|}{$0.83 \mathrm{ab}$} & \multicolumn{2}{|c|}{74.30} \\
\hline Kompos & 14.38 & \multicolumn{2}{|c|}{$0.73 \mathrm{ab}$} & \multicolumn{2}{|c|}{60.17} \\
\hline Kontrol & 13.39 & \multicolumn{2}{|c|}{$0.63 \mathrm{~b}$} & \multicolumn{2}{|c|}{52.50} \\
\hline \multicolumn{6}{|c|}{$\begin{array}{l}\text { Keterangan: Angka yang diikuti oleh huruf yang berbeda pada kolom yang sama menunjukkan berbeda nyata berdasarkan uji tukey } \\
\text { pada taraf 5\% }\end{array}$} \\
\hline \multirow{2}{*}{\multicolumn{4}{|c|}{$\begin{array}{ll}\text { Pakcoi (Brassica rapa L.) } & \begin{array}{l}\text { komponen pertumbu } \\
\text { setiap minggu pengan } \\
\text { ragam pakcoi dapat di }\end{array} \\
\text { Perlakuan jenis pupuk organik memberikan } & \\
\text { pengaruh yang sangat nyata terhadap seluruh } & \\
\text { Tabel 13. Rekapitulasi sidik ragam hasil percobaan pada pakcoi Gardena }\end{array}$}} & \multicolumn{2}{|c|}{$\begin{array}{l}\text { hasil panen pada } \\
\text { sil rekapitulasi sidik } \\
\text { a Tabel } 13 \text {. }\end{array}$} \\
\hline & & & & & \\
\hline \multirow{2}{*}{\multicolumn{2}{|c|}{ Peubah }} & \multicolumn{4}{|c|}{ Umur Tanaman (MST) } \\
\hline & & 1 & 2 & 3 & 4 \\
\hline \multicolumn{2}{|l|}{ Tinggi Tanaman } & $* *$ & $* *$ & $* *$ & $* *$ \\
\hline \multicolumn{2}{|l|}{ Panjang Daun } & $* *$ & $* *$ & $* *$ & $* *$ \\
\hline \multicolumn{2}{|l|}{ Lebar Daun } & $* *$ & $* *$ & $* *$ & $* *$ \\
\hline \multicolumn{2}{|l|}{ Jumlah Daun } & $* *$ & $* *$ & $* *$ & $* *$ \\
\hline \multicolumn{2}{|l|}{ Bobot Tajuk/Tanaman } & - & - & - & $* *$ \\
\hline \multicolumn{2}{|l|}{ Bobot Tajuk/Bedeng } & - & - & - & $* *$ \\
\hline \multicolumn{2}{|l|}{ Bobot Layak Pasar/Bedeng } & - & - & - & $* *$ \\
\hline \multicolumn{2}{|l|}{ Panjang Akar } & - & - & - & $* *$ \\
\hline \multicolumn{2}{|l|}{ Bobot Akar/Tanaman } & - & - & - & $* *$ \\
\hline \multicolumn{2}{|l|}{ Bobot Akar/Bedeng } & - & - & - & $* *$ \\
\hline
\end{tabular}

Keterangan : ${ }^{* *}=$ berbeda sangat nyata pada uji $\mathrm{F} 1 \% ;-$ = tidak dilakukan pengamatan; MST = minggu sebelum tanam

Pemberian pupuk kandang ayam kandang ayam meningkatkan tinggi tanaman menghasilkan tinggi tanaman terbesar. Pupuk $478.55 \%$ pada kontrol di 4 MST (Tabel 14). 
Bul. Agrohorti 3 (2) : $262-275$ (2015)

Tabel 14. Rata-rata tinggi tanaman pakcoi Gardena pada berbagai jenis pupuk organik

\begin{tabular}{lcccc}
\hline \multirow{2}{*}{ Jenis Pupuk Organik } & \multicolumn{4}{c}{ Umur (MST) } \\
\cline { 2 - 5 } & 1 & 2 & 3 & 4 \\
\hline & & & $-------\mathrm{cm}------$ & $19.96 \mathrm{a}$ \\
Pukan Ayam & $8.10 \mathrm{a}$ & $15.20 \mathrm{a}$ & $19.41 \mathrm{a}$ & $9.33 \mathrm{~b}$ \\
Pukan Sapi & $4.13 \mathrm{~b}$ & $5.67 \mathrm{~b}$ & $7.60 \mathrm{~b}$ & $11.37 \mathrm{~b}$ \\
Kompos & $4.09 \mathrm{~b}$ & $6.00 \mathrm{~b}$ & $8.49 \mathrm{bc}$ & $3.45 \mathrm{c}$ \\
\hline
\end{tabular}

Keterangan: Angka yang diikuti oleh huruf yang berbeda pada kolom yang sama menunjukkan berbeda nyata berdasarkan uji tukey pada $\operatorname{taraf} 5 \%$.

Tabel 15 menunjukkan bahwa pupuk kandang ayam menghasilkan panjang daun lebih panjang dibandingkan dengan perlakuan jenis pupuk organik lainnya. Tabel 15 menunjukkan peningkatan panjang daun dengan pemberian pupuk kandang ayam yaitu sebesar $344.91 \%$ dibandingkan dengan kontrol pada 4 MST.

Tabel 15. Rata-rata panjang daun pakcoi Gardena pada berbagai jenis dosis pupuk

\begin{tabular}{|c|c|c|c|c|}
\hline \multirow{2}{*}{$\begin{array}{c}\text { Jenis Pupuk } \\
\text { Organik } \\
\end{array}$} & \multicolumn{4}{|c|}{ Umur (MST) } \\
\hline & 1 & 2 & 3 & 4 \\
\hline & \multicolumn{4}{|c|}{ 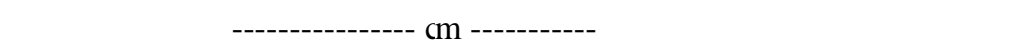 } \\
\hline Pukan Ayam & $6.79 \mathrm{a}$ & $10.26 \mathrm{a}$ & $11.89 \mathrm{a}$ & $12.68 \mathrm{a}$ \\
\hline Pukan Sapi & $3.15 b$ & $4.29 \mathrm{~b}$ & $4.97 b$ & $6.10 \mathrm{bc}$ \\
\hline Kompos & $3.07 \mathrm{~b}$ & $4.36 \mathrm{~b}$ & $5.20 \mathrm{~b}$ & $6.83 b$ \\
\hline Kontrol & $2.16 \mathrm{~b}$ & $2.53 \mathrm{~b}$ & $2.81 \mathrm{c}$ & $2.85 \mathrm{c}$ \\
\hline
\end{tabular}

Keterangan: Angka yang diikuti oleh huruf yang berbeda pada kolom yang sama menunjukkan berbeda nyata berdasarkan uji tukey pada taraf $5 \%$.

Pupuk kandang ayam menghasilkan lebar daun terbesar dibandingkan dengan pupuk kandang sapi, pupuk kompos dan kontrol. Lebar daun dengan pemberian pupuk kandang ayam meningkat sebesar $534.31 \%$ dibandingkan kontrol pada 4 MST (Tabel 16).

Tabel 16. Rata-rata lebar daun pakcoi Gardena pada berbagai jenis pupuk organik

\begin{tabular}{lcccc}
\hline \multirow{2}{*}{ Jenis Pupuk Organik } & \multicolumn{5}{c}{ Umur (MST) } \\
\cline { 2 - 5 } & 1 & 2 & 3 & 4 \\
\hline & & $------\mathrm{cm}-----$ & \\
Pukan Ayam & $3.43 \mathrm{a}$ & $5.24 \mathrm{a}$ & $6.18 \mathrm{a}$ & $6.47 \mathrm{a}$ \\
Pukan Sapi & $1.23 \mathrm{~b}$ & $1.72 \mathrm{~b}$ & $2.31 \mathrm{~b}$ & $2.64 \mathrm{bc}$ \\
Kompos & $1.22 \mathrm{~b}$ & $1.78 \mathrm{~b}$ & $2.46 \mathrm{~b}$ & $3.86 \mathrm{~b}$ \\
Kontrol & $0.78 \mathrm{~b}$ & $0.86 \mathrm{~b}$ & $0.90 \mathrm{~b}$ & $1.02 \mathrm{c}$ \\
\hline Keterangan: & Angka yang diikuti oleh huruf yang berbeda pada kolom yang sama menunjukkan berbeda nyata berdasarkan uji tukey \\
& pada taraf 5\%.
\end{tabular}

Pupuk kandang ayam menghasilkan jumlah daun tertinggi dibandingkan dengan pupuk organik lainnya. Berdasarkan tabel 17, jumlah daun dengan pemberian pupuk kandang ayam meningkat sebesar 190.79\% dibandingkan kontrol pada 4 MST. 
Bul. Agrohorti 3 (2) : 263 - 275 (2015)

Tabel 17. Rata-rata jumlah daun pakcoi Gardena pada berbagai jenis pupuk organik

\begin{tabular}{lrrrr}
\hline \multirow{2}{*}{ Jenis Pupuk Organik } & \multicolumn{5}{c}{ Umur (MST) } \\
\cline { 2 - 5 } & 1 & 2 & 3 & 4 \\
\hline & & & $-----\mathrm{cm}----$ & \\
Pukan Ayam & $3.51 \mathrm{a}$ & $4.57 \mathrm{a}$ & $6.23 \mathrm{a}$ & $6.95 \mathrm{a}$ \\
Pukan Sapi & $2.22 \mathrm{~b}$ & $2.93 \mathrm{~b}$ & $3.69 \mathrm{~b}$ & $3.98 \mathrm{~b}$ \\
Kompos & $2.54 \mathrm{~b}$ & $2.75 \mathrm{~b}$ & $3.50 \mathrm{~b}$ & $3.66 \mathrm{~b}$ \\
Kontrol & $2.11 \mathrm{~b}$ & $2.33 \mathrm{~b}$ & $2.33 \mathrm{c}$ & $2.39 \mathrm{~b}$ \\
\hline
\end{tabular}

Keterangan: Angka yang diikuti oleh huruf yang berbeda pada kolom yang sama menunjukkan berbeda nyata berdasarkan uji tukey pada taraf $5 \%$.

Hasil panen tajuk tertinggi dihasilkan dari perlakuan pupuk kandang ayam. Tabel 18 menunjukkan pupuk kandang ayam menghasilkan bobot tajuk per tanaman sebesar $22.45 \mathrm{~g}$, bobot tajuk per bedeng sebesar $638.71 \mathrm{~g}$ dan bobot layak pasar per bedeng $630.99 \mathrm{~g}$.

Tabel 18. Rata-rata hasil panen tajuk pakcoi Gardena pada perlakuan jenis pupuk organik

\begin{tabular}{|c|c|c|c|}
\hline $\begin{array}{c}\text { Jenis Pupuk } \\
\text { Organik }\end{array}$ & $\begin{array}{l}\text { Bobot Tajuk } \\
\text { per Tanaman }\end{array}$ & $\begin{array}{c}\text { Bobot } \\
\text { Tajuk } \\
\text { per } \\
\text { Bedeng }\end{array}$ & $\begin{array}{c}\text { Bobot } \\
\text { Layak } \\
\text { Pasar per } \\
\text { Bedeng }\end{array}$ \\
\hline & & - & \\
\hline Pukan Ayam & $22.45 a$ & $638.71 \mathrm{a}$ & $630.99 a$ \\
\hline Pukan Sapi & $8.16 \mathrm{~b}$ & $169.53 b$ & $184.55 b$ \\
\hline Kompos & $9.36 \mathrm{~b}$ & $83.77 b c$ & $79.05 \mathrm{bc}$ \\
\hline Kontrol & $0.21 \mathrm{c}$ & $0.94 c$ & $0.00 \mathrm{c}$ \\
\hline
\end{tabular}

Keterangan: Angka yang diikuti oleh huruf yang berbeda pada kolom yang sama menunjukkan berbeda nyata berdasarkan uji tukey pada taraf $5 \%$.

Hasil panen akar tertinggi dihasilkan dari perlakuan pupuk kandang ayam. Panjang akar dengan perlakuan pupuk kandang ayam tidak berbeda nyata dengan perlakuan pupuk kandang sapi dan pupuk kompos. Panjang akar dengan pemberian pupuk kandang ayam meningkat 219.19\% dibandingkan kontrol. Bobot akar per tanaman dan bobot akar per bedeng tertinggi yaitu $0.97 \mathrm{~g}$ dan $34.06 \mathrm{~g}$ (Tabel 19).

Tabel 19. Rata-rata hasil panen akar pakcoi Gardena pada perlakuan jenis pupuk organik

\begin{tabular}{|c|c|c|c|}
\hline Jenis Pupuk Organik & $\begin{array}{c}\text { Panjang } \\
\text { Akar }\end{array}$ & $\begin{array}{c}\text { Bobot } \\
\text { Akar per } \\
\text { Tanaman }\end{array}$ & $\begin{array}{c}\text { Bobot } \\
\text { Akar per } \\
\text { Bedeng }\end{array}$ \\
\hline & $\mathrm{cm}$ & --------g---" & \\
\hline Pukan Ayam & $17.35 \mathrm{a}$ & $0.97 \mathrm{a}$ & $34.06 \mathrm{a}$ \\
\hline Pukan Sapi & $16.58 \mathrm{a}$ & $0.68 \mathrm{~b}$ & $8.36 \mathrm{~b}$ \\
\hline Kompos & $16.23 \mathrm{a}$ & $0.61 b$ & $6.98 \mathrm{bc}$ \\
\hline Kontrol & $3.06 \mathrm{~b}$ & $0.05 c$ & $0.22 \mathrm{c}$ \\
\hline $\begin{array}{c}\text { Keterangan: Angka yang diikuti oleh huruf yang berbeda pada } \\
\text { taraf 5\% }\end{array}$ & $m$ yang & kan berbeda & kan uji tukey pada \\
\hline Selada (Lactuca sativa L.) & \multirow{2}{*}{\multicolumn{3}{|c|}{$\begin{array}{l}\text { pertumbuhan dan hasil panen pada setiap minggu } \\
\text { pengamatan kecuali jumlah daun pada } 1 \mathrm{MST} \text {. Hasil } \\
\text { rekapitulasi sidik ragam selada dapat dilihat pada } \\
\text { tabel } 20 \text {. }\end{array}$}} \\
\hline \begin{tabular}{l}
\multicolumn{4}{c}{ Perlakuan jenis pupuk organik memberikan } \\
pengaruh sangat nyata terhadap komponen
\end{tabular} & & & \\
\hline
\end{tabular}


Bul. Agrohorti 3 (2) : $262-275$ (2015)

Tabel 20. Rekapitulasi sidik ragam hasil percobaan pada selada keriting Chia Tai

\begin{tabular}{|c|c|c|c|c|}
\hline \multirow{2}{*}{ Peubah } & \multicolumn{4}{|c|}{ Umur Tanaman (MST) } \\
\hline & 1 & 2 & 3 & 4 \\
\hline Tinggi Tanaman & $* *$ & $* *$ & $* *$ & $* *$ \\
\hline Lebar Daun & $* *$ & $* *$ & $* *$ & $* *$ \\
\hline Jumlah Daun & $*$ & $* *$ & $* *$ & $* *$ \\
\hline Bobot Tajuk/Tanaman & - & - & - & $* *$ \\
\hline Bobot Tajuk/Bedeng & - & - & - & ** \\
\hline Bobot Layak Pasar/Bedeng & - & - & - & ** \\
\hline Panjang Akar & - & - & - & $* *$ \\
\hline Bobot Akar/Tanaman & - & - & - & $* *$ \\
\hline Bobot Akar/Bedeng & - & - & - & $* *$ \\
\hline
\end{tabular}

Keterangan : **= berbeda sangat nyata pada uji F 1\%; - = tidak dilakukan pengamatan; MST = minggu sebelum tanam

Pupuk kandang ayam menghasilkan tinggi tanaman selada tertinggi. Tabel 17 menunjukkan bahwa dibandingkan dengan kontrol, pupuk kandang ayam meningkatkan tinggi tanaman sebesar $604.36 \%$ pada 4 MST.

Tabel 21. Rata-rata tinggi tanaman selada keriting Chia Tai pada berbagai jenis pupuk organik

\begin{tabular}{lcrrr}
\hline \hline \multirow{2}{*}{ Jenis Pupuk Organik } & \multicolumn{5}{c}{ Umur (MST) } & 4 \\
\cline { 2 - 5 } & 1 & 2 & 3 & $17.75 \mathrm{a}$ \\
Pukan Ayam & & & $------\mathrm{cm} \mathrm{--1---}$ & $9.68 \mathrm{~b}$ \\
Pukan Sapi & $6.56 \mathrm{a}$ & $8.74 \mathrm{a}$ & $12.06 \mathrm{a}$ & $4.49 \mathrm{c}$ \\
Kompos & $3.87 \mathrm{~b}$ & $5.02 \mathrm{~b}$ & $6.98 \mathrm{~b}$ & $2.52 \mathrm{c}$ \\
Kontrol & $2.58 \mathrm{bc}$ & $2.95 \mathrm{bc}$ & $3.35 \mathrm{c}$ & $2.11 \mathrm{c}$ \\
\hline
\end{tabular}

Keterangan: Angka yang diikuti oleh huruf yang berbeda pada kolom yang sama menunjukkan berbeda nyata berdasarkan uji tukey pada taraf 5\%

Lebar daun selada tertinggi dihasilkan dari perlakuan pupuk kandang ayam. Berdasarkan tabel 22, lebar daun dengan perlakuan pupuk kandang ayam mengalami peningkatan $475.16 \%$ dibandingkan dengan kontrol pada 4 MST.

Tabel 22. Rata-rata lebar daun selada keriting Chia Tai pada berbagai jenis pupuk organik

\begin{tabular}{|c|c|c|c|c|}
\hline \multirow{2}{*}{ Jenis Pupuk Organik } & \multicolumn{4}{|c|}{ Umur (MST) } \\
\hline & 1 & 2 & 3 & 4 \\
\hline & \multicolumn{4}{|c|}{------ cm ----- } \\
\hline Pukan Ayam & $3.29 \mathrm{a}$ & $5.94 \mathrm{a}$ & $7.09 \mathrm{a}$ & $9.03 \mathrm{a}$ \\
\hline Pukan Sapi & $1.85 \mathrm{~b}$ & $2.93 b$ & $3.65 \mathrm{~b}$ & $5.41 \mathrm{~b}$ \\
\hline Kompos & $1.20 \mathrm{~b}$ & $1.45 \mathrm{c}$ & $1.58 \mathrm{c}$ & $2.07 \mathrm{c}$ \\
\hline Kontrol & $0.98 \mathrm{~b}$ & $1.01 \mathrm{c}$ & $1.22 \mathrm{c}$ & $1.57 \mathrm{c}$ \\
\hline
\end{tabular}

Jumlah daun tertinggi dihasilkan dari perlakuan pupuk kandang ayam. Berdasarkan tabel 23, lebar daun dengan perlakuan pupuk kandang ayam mengalami peningkatan $77.12 \%$ dibandingkan dengan kontrol pada 4 MST. 
Bul. Agrohorti 3 (2) : 263 - 275 (2015)

Tabel 23. Rata-rata jumlah daun selada keriting Chia Tai pada perlakuan jenis pupuk organik

\begin{tabular}{lcccc}
\hline \multirow{2}{*}{ Jenis Pupuk Organik } & \multicolumn{4}{c}{ Umur (MST) } \\
\cline { 2 - 5 } & 1 & 2 & 3 & 4 \\
\hline Pukan Ayam & $4.30 \mathrm{a}$ & $5.02 \mathrm{a}$ & $6.17 \mathrm{a}$ & $6.27 \mathrm{a}$ \\
Pukan Sapi & $3.97 \mathrm{a}$ & $4.42 \mathrm{~b}$ & $4.99 \mathrm{~b}$ & $5.37 \mathrm{~b}$ \\
Kompos & $3.66 \mathrm{~b}$ & $3.95 \mathrm{ab}$ & $4.02 \mathrm{c}$ & $4.19 \mathrm{~b}$ \\
Kontrol & $2.92 \mathrm{~b}$ & $3.00 \mathrm{~b}$ & $3.22 \mathrm{c}$ & $3.54 \mathrm{~b}$ \\
\hline Keterangan: Angka yang diikuti oleh huruf yang berbeda pada kolom yang sama menunjukkan berbeda nyata berdasarkan uji tukey pada \\
$\quad$ taraf 5\%.
\end{tabular}

Perlakuan pupuk kandang ayam memberikan hasil panen tajuk selada tertinggi.

Tabel 24 menunjukkan bobot tajuk per tanaman dan

bobot tajuk per bedeng yaitu $61.90 \%$ dan $146.69 \%$ lebih besar dibandingkan kontrol. Bobot layak pasar per bedeng tertinggi yaitu $533.20 \mathrm{~g}$.

Tabel 24. Rata-rata hasil panen tajuk selada keriting Chia Tai pada perlakuan jenis pupuk organik

\begin{tabular}{lccc}
\hline $\begin{array}{c}\text { Jenis Pupuk } \\
\text { Organik }\end{array}$ & $\begin{array}{c}\text { Bobot } \\
\text { Tajuk } \\
\text { per } \\
\text { Tanaman }\end{array}$ & $\begin{array}{c}\text { Bobot Tajuk } \\
\text { per Bedeng }\end{array}$ & $\begin{array}{c}\text { Bobot } \\
\text { Layak } \\
\text { Pasar per } \\
\text { Bedeng }\end{array}$ \\
\hline & & $---------\mathrm{g}------------$ & \\
Pukan Ayam & $15.85 \mathrm{a}$ & $533.20 \mathrm{a}$ & $533.20 \mathrm{a}$ \\
Pukan Sapi & $10.66 \mathrm{~b}$ & $326.50 \mathrm{~b}$ & $317.48 \mathrm{~b}$ \\
Kompos & $1.52 \mathrm{c}$ & $46.55 \mathrm{c}$ & $0.00 \mathrm{c}$ \\
Kontrol & $0.43 \mathrm{c}$ & $4.98 \mathrm{c}$ & $0.00 \mathrm{c}$ \\
\hline Keterangan: & Angka yang diikuti oleh huruf yang berbeda pada kolom yang sama menunjukkan berbeda nyata berdasarkan uji tukey \\
& &
\end{tabular}

Perlakuan pupuk kandang sapi memberikan hasil panen akar selada tertinggi. Tabel 25 menunjukkan panjang akar selada dengan perlakuan pupuk kandang sapi meningkat sebesar $284.39 \%$ dibandingkan kontrol. Bobot akar per tanaman dan bobot akar per bedeng dengan perlakuan pupuk kandang sapi memberikan hasil tertinggi namun tidak berbeda nyata dengan pupuk kandang ayam

Tabel 25. Rata-rata hasil panen akar selada kertiting Chia Tai pada perlakuan jenis pupuk organik

\begin{tabular}{lccc}
\hline \multicolumn{1}{c}{ Jenis Pupuk Organik } & Panjang & Bobot & Bobot \\
& Akar & $\begin{array}{c}\text { Akar per } \\
\text { Tanaman }\end{array}$ & $\begin{array}{c}\text { Akar per } \\
\text { Bedeng }\end{array}$ \\
\hline & $\mathrm{cm}$ & $----\mathrm{g}-----$ & \\
Pukan Ayam & $9.54 \mathrm{~b}$ & $0.770 \mathrm{a}$ & $22.67 \mathrm{a}$ \\
Pukan Sapi & $10.34 \mathrm{a}$ & $0.773 \mathrm{a}$ & $27.24 \mathrm{a}$ \\
Kompos & $5.45 \mathrm{c}$ & $0.19 \mathrm{~b}$ & $6.51 \mathrm{~b}$ \\
Kontrol & $2.69 \mathrm{~d}$ & $0.13 \mathrm{~b}$ & $1.74 \mathrm{~b}$ \\
\hline
\end{tabular}

Keterangan: Angka yang diikuti oleh huruf yang berbeda pada kolom yang sama menunjukkan berbeda nyata berdasarkan uji tukey pada taraf 5\%.

Tinggi tanaman terbesar pada keempat jenis sayuran yang diuji dihasilkan dari pemberian pupuk kandang ayam. Hal ini diduga karena kemampuan pupuk kandang ayam dalam menyediakan bahan organik lebih tinggi dibandingkan pupuk kandang sapi maupun pupuk kompos. Bahan organik berperan mengikat Al yang banyak terkandung dalam tanah masam. Tanah yang digunakan dalam percobaan bersifat sangat masam dengan $\mathrm{pH}$ sebesar 4.2. Pengikatan Al oleh bahan organik menyebabkan lepasnya berbagai unsur hara (terutama fosfor) yang sebelumnya terikat oleh $\mathrm{Al}$ sehingga hara dapat digunakan oleh tanaman untuk tumbuh dan berkembang (Tan, 1993). 
Panjang daun maupun lebar daun caisin dan pakcoi serta lebar daun selada dengan perlakuan pupuk kandang ayam menunjukkan hasil tertinggi diantara perlakuan jenis pupuk organik lain. Hal ini diduga karena kandungan nitrogen pupuk kandang ayam lebih tinggi dibandingkan pupuk kandang sapi dan kompos. Menurut Plaster (2003) nitrogen lebih optimum dalam menunjang pertumbuhan bagian vegetatif dibandingkan bagian generatif dan penting bagi tanaman sayuran yang dikonsumsi bagian tajuknya. Plaster (2003) menuliskan pula bahwa pemberian nitrogen dalam jumlah yang cukup, dapat menghasilkan tanaman yang vigor dan ukuran daun yang besar.

Jumlah daun tertinggi dimiliki oleh tanaman dengan perlakuan pupuk kandang ayam. Diduga hal ini disebabkan oleh kandungan kalium pupuk kandang ayam yang lebih tinggi dibandingkan pupuk organik lainnya. Kalium berperan penting dalam transpor fotosintat (proses phloem loading) ke bagian sink (Krishna, 2002). Salah satu bagian sink yang kompetitif pada masa pertumbuhan vegetatif adalah daun muda atau tunas yang sedang tumbuh (Gardner et al., 1991; Salisbury dan Ross, 1995). Semakin banyak tunas yang memperoleh hara maka jumlah tunas yang tumbuh dan berkembang menjadi daun lebih tinggi.

Pupuk kandang ayam menghasilkan bobot tajuk per tanaman dan bobot tajuk per bedeng keempat jenis sayuran lebih tinggi dibandingkan perlakuan lainnya. Bobot tajuk per tanaman caisin, pakcoi dan selada dengan perlakuan pupuk kandang ayam meningkat sebesar $205.82 \%, 184.00 \%$ dan $358.61 \%$ dibandingkan dengan kontrol. Diduga hal tersebut terjadi akibat tinggi tanaman, panjang daun, lebar daun dan jumlah daun dengan perlakuan pupuk kandang ayam lebih tinggi dibandingkan pupuk organik lainnya. Gardner et al. (1991) menyatakan ukuran tajuk yang tinggi merupakan indikasi bahwa tanaman memprioritaskan cadangan makanan hasil fotosintesis disimpan di bagian tajuk sehingga hasil panen meningkat.

Perlakuan pupuk kandang ayam menghasilkan panjang akar caisin tertinggi, yaitu $199.00 \%$ lebih besar dibandingkan kontrol. Hal ini mengindikasikan bahwa pupuk kandang ayam memiliki kandungan bahan organik yang lebih tinggi dibandingkan pupuk organik lainnya. Sesuai dengan pernyataan Wolf dan Snyder (2003) pupuk organik merupakan salah satu jenis pembenah tanah yang dapat meningkatkan jumlah $\mathrm{P}$ tersedia tanah. Fakta ini sesuai dengan hasil penelitian Noor (2003) yang menunjukkan tanah yang diberi dan tidak Anita Maryam, Anas D. Susila, Juang Gema Kartika diberi pupuk kandang mengandung 2.47 dan 1.53 $\mathrm{kg} \mathrm{P} / \mathrm{ha}$. Menurut Islami dan Utomo (1995) fosfor dalam tanah dapat meningkatkan aktivitas auksin yang berperan meningkatkan pertumbuhan akar.

Panjang akar tanaman selada yang diberi pupuk kandang sapi $(10.34 \mathrm{~cm})$ lebih panjang dibandingkan dengan yang diberi pupuk kandang ayam $(9.54 \mathrm{~cm})$. Diduga kandungan hara pupuk kandang ayam yang lebih besar daripada kandungan hara pupuk kandang sapi menjadi penyebabnya. Menurut Salisbury dan Ross (1995) selain faktor genetik, morfologi akar ditentukan pula oleh keadaan hara tanah. Apabila hara tersedia dalam jumlah yang cukup maka tanaman akan membentuk sistem akar yang dangkal. Sebaliknya, tanaman dengan perlakuan pupuk kandang sapi cenderung memperluas akar untuk mendapatkan hara.

Tanaman sayuran dengan pemberian pupuk kandang ayam menghasilkan rata-rata bobot tajuk per tanaman yang tertinggi dibandingkan jenis pupuk organik lainnya. Namun demikian, hasil panen ini lebih rendah dibandingkan bobot panen per tanaman dengan budidaya secara konvensional. Diduga hal ini disebabkan oleh tingkat mineralisasi pupuk kandang ayam masih rendah sehingga jumlah hara yang tersedia belum mencukupi kebutuhan hara untuk memproduksi fotosintat. Tingkat mineralisasi $\mathrm{N}$ pupuk organik pada umumnya hanya berkisar $-2.1 \%$ hingga $9.1 \%$ dalam 5 bulan (Stofella et al., 1997).

\section{KESIMPULAN}

Caisin (Brassica juncea) dan pakcoi (Brassica rapa L.) dengan pemberian pupuk kandang ayam memiliki hasil tertinggi pada komponen pertumbuhan dan hasil panen. Kangkung (Ipomoea reptans) dengan pemberian pupuk kandang ayam memiliki hasil tertinggi pada komponen tinggi tanaman, jumlah daun, bobot tajuk per tanaman, bobot tajuk per bedeng, bobot layak pasar per bedeng, dan bobot akar per tanaman. Selada (Lactuca sativa L.) dengan pemberian pupuk kandang ayam memiliki hasil tertinggi pada komponen tinggi tanaman, lebar daun, jumlah daun, bobot tajuk per tanaman, bobot tajuk per bedeng, bobot layak pasar per bedeng. Pupuk kandang sapi menghasilkan panjang akar tertinggi. Pupuk kandang ayam memiliki kandungan nitrogen, fosfor dan kalium tertinggi. Pupuk kandang sapi memiliki kadar air tertinggi. 
Bul. Agrohorti 3 (2) : 263 - 275 (2015)

\section{DAFTAR PUSTAKA}

[BPS] Badan Pusat Statistik. 2005. Population of Indonesia by Province 1971, 1980, 1990, 1995 and 2000 [Internet]. [Diunduh 07 Juli 2008]. Tersedia pada : http://www.bps.go.id.

Direktoral Jendral Hortikultura. 2008. Produksi Tanaman Sayuran di Indonesia Periode 2003 - 2007. Departemen Pertanian.

[FAO] Food Agriculture Organisation. 2007. Data kebutuhan pangan tahun 2007 [Internet]. [Diunduh 24 November 2007]. Tersedia pada : http://www.faostat.fao.org

Gardner, F. P., Pearce R. B., Mitchell, R. L. 1991. Fisiologi Tanaman Budidaya. Jilid pertama. Penerjemah: Herawati Susilo. Jakarta (ID) : UI-Press. 428 hal

Islami, T., Utomo, W. H. 1995. Hubungan Tanah, Air dan Tanaman. Semarang (ID) : IKIP Semarang. 297 hal.

Krishna, K. R. 2002. Potassium in Soil and Its Influence on Crop Growth and Yield, $\mathrm{p}$. 141-153. In: K. R. Krishna (Ed.). Soil Fertility and Crop Production. Science Publishers Inc. USA.

Krishnawati, D. 2003. Pengaruh pemberian pupuk kascing terhadap pertumbuhan vegetatif tanaman kentang (Solanum tuberosum). KAPPA. 4 (1): 9-12.

Las, I., Subagyono, K., Setiyanto, A.P. 2006. Isu dan pengelolaan lingkungan dalam revitalisasi pertanian. Jurnal Litbang Pertanian. 25(3): 106-114.
Noor, A. 2003. Pengaruh fosfat alam dan kombinasi bakteri pelarut fosfat dengan pupuk kandang terhadap $\mathrm{P}$ tersedia dan pertumbuhan kedelai pada ultisol. Buletin Agronomi. 31(3): 100-106.

Plaster, E. J. 2003. Soil Science and Management. Delmar Learning Inc. $4^{\text {th }} \mathrm{ed}$. United States (USA). 384 p.

Salisbury, F. B., Ross, C. W. 1995. Fisiologi Tumbuhan. Jilid pertama. Penerjemah: D. R. Lukman dan Sumaryono. Bandung (ID) : ITB Press. 241 hal.

Singh, B., Kumar, M., Singh, V. 2006. Nylon mesh screens reduce incidence of Leaf Curl Virus (LCV) and improve yield in sweet pepper. Journal of Vegetable Science. 12 (1): $65-70$.

Stoffella, P. J., Li, Y., Roe, N. E., Ozores-Hampton, M., Graetz, D. A. 1997. Utilization of Organic Waste Compost in Vegetable Crop Production Systems, p. 252-269. $I n$ : R. A. Moris (Ed.). Managing Soil Fertility for Intensive Vegetable Production Systems in Asia. Asian Vegetable Research and Development Center. Shanhua. Taiwan.

Tan, K. H. 1993. Principles of Soil Chemistry. $2^{\text {nd }}$ ed. . New York (USA) : Marcel Dekker Inc. $362 \mathrm{p}$.

Wolf, B., Snyder, G.H. 2003. Sustainable Soils: The Place of Organic Matter in Sustaining Soils and Their Productivity. America (USA) : The Haworth Press Inc 352 p 